\title{
ある厅舎の耐震性について
}

\section{正会員 贲天義久*}

1. 序本研究は鉄骨鉄筋コンクリート造地下 1 階地 上12階ペントハウス 2 階のある庁舎の䙲震性を既往の応 答曲線によって検訢したものである。本打舎の主要な雨 面図之断面図を図一1 亿示す。本庁舎の高層建罍として の特徵は 8 階腰以上に楐舅コンクリートを使用している ことと耐震壁が入っているととである。

2. 解析用モデルと仮定 本建物を剪断层動型の 13 質点系に置換する。質量は床仿置に集中しているもの之

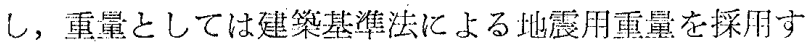
る。ペントハウスの重量は 13 階に合める。㴊性は梁休 は㓘として柱や壁によって生ずるものとする。復元力特 性:は完全弾望性も含めた bilinear 型とする。地盤は蜼 好で基䃈固定として解析する。減衰はないものとする。

3. 初期剛性 無壁ラーメンについては渆㕅仮定のも とに $k=12 E K / h^{2}$ に上って求める。乙てに $E$ は柱材料 の巣性係数， $K$ は柱の剛度， $h$ は階高である。有暂ラ ーメンについてはまず曲げと剪断と㓩域を䓅慮した 1 ス パンラーメンに対して弾力係数を求める。ての弹力係数 は上下隣接層以外の層の影響を含んでいるので，てれを 無壁ラーメンに扔ける剮床仮定と合せるため，近似的に 弾力係数表の対角線上之その雨隣の弾力係数のみを残し て他は 0 とする。とうすれば基本振動型に近い振動をす るときは曲げの影響も含んだ煎断型の弾力係数が得られ るととになる。てのようにして求まった备ラーメンの初 期㓮性を無壁ラーメン 10.5 通り，有壁ラーメン 3.5 通 りの割合で加党合せて建物全体の初期㴊性とする。

4. 降伏層剪断力 無壁ラーメンについては㴊床仮定

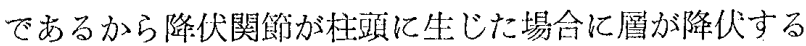
ものとして降伏層尊断力算出する。乙の場合自重によ る軸方向力を考慮し，学会の「鉄筋コンクリート構造の

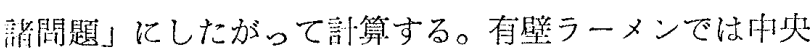
スパンの梁がまず降伏するものとし，梁の降伏モーメン トと自重による柱檕方向力は柱が角担し，剪断力は壁が 负担するものと仮定して終局酎少算出する。無暨・有 䬺ラーメンを加え合せた復元力特性は备々の街重変形曲 線を画いて判断せ称ばならない。壁の終肩耐力にはひび われ楖力,スリップ状耐力, 補強筋のみの㧧さの 3 種があ る。前 2 者は無壁ラーメンの树力より大であるが，篟の 勒性率 14 以上飞おいて補強筋の強さとなり無壁ラーメ ンの耐力より小さくなる。そてで壁の耐力は無壁ラーメ ンの附力と同じと考克る。てのようにして上の $2 ， 3 ， 4$

* 神戸大学教授・主博 $* *$ 同助教授 $* * *$ 网大学院生
网水畑耕治炏同 ○種 泰雄炏水

表-1

\begin{tabular}{|c|c|c|c|c|c|c|c|c|}
\hline \multirow[b]{2}{*}{ 建物全体 } & \multicolumn{2}{|l|}{ 重 } & \multicolumn{2}{|c|}{ 初 期 剧 性 } & \multicolumn{2}{|c|}{ 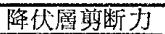 } & \multicolumn{2}{|c|}{ 弾泩限翌住 } \\
\hline & $\begin{array}{l}\text { 絶対优 } \\
(\mathrm{t})\end{array}$ & 比 & $\begin{array}{l}\text { 絇 刘 值 } \\
(\mathrm{t} / \mathrm{cm})\end{array}$ & 比 & $\begin{array}{c}\text { 絶対值 } \\
(\mathrm{t})\end{array}$ & 此 & \begin{tabular}{|c|} 
緭対値 \\
$(\mathrm{cm})$
\end{tabular} & 比 \\
\hline $13 \mathrm{~F}$ & 2579.0 & 0.874 & $12,723.08$ & 0.41 & $2,528.00$ & 0.388 & 0.199 & 0.940 \\
\hline $12 \mathrm{~F}$ & 2047.0 & & $14,515.07$ & 0.47 & $2,592.00$ & 0.397 & 0.178 & 0.840 \\
\hline $11 \mathrm{~F}$ & 2047.0 & 0.695 & $14,868.75$ & 0.48 & $2,656.00$ & 0.407 & 0.179 & 0.845 \\
\hline $10 \mathrm{~F}$ & 2047.0 & 0.695 & $14,931.67$ & 0.48 & $2,879.98$ & 0.441 & 0.193 & 0.910 \\
\hline $9 \mathrm{~F}$ & 2047.0 & 0.695 & $14,942.72$ & 0.48 & $2,944.00$ & 0.451 & 0.197 & 0.930 \\
\hline $\bar{F}$ & 2352.0 & 0.797 & $19,198.27$ & 0.62 & $3,551,99$ & 0.544 & 0.185 & 0.873 \\
\hline $\mathrm{F}$ & 2411.0 & 0.816 & $19,263.04$ & 0.62 & $3,487.99$ & 0.534 & 0.181 & 0.854 \\
\hline $6 \mathrm{~F}$ & 2599.0 & 0.880 & $29,261.66$ & 0.95 & $5,519.99$ & 0.845 & 0.189 & 0.892 \\
\hline $5 \mathrm{~F}$ & 2599.0 & 0.880 & $29,291.21$ & 0.95 & 5,53 & 0.848 & 0.189 & 0.892 \\
\hline $4 \mathrm{~F}$ & 2599.0 & 0.880 & $30,891.95$ & 1.00 & 5,567 & 0.854 & 0.180 & 0.850 \\
\hline $\mathrm{F}$ & 2599.0 & 0.880 & $35,596.13$ & 1.1 & 5,648 & 0.865 & 0.159 & 0.750 \\
\hline $2 \mathrm{~F}$ & 2949.0 & 1.000 & $30,626.54$ & 1.0 & 6,46 & 1.0 & 0.212 & 1.000 \\
\hline $1 \mathrm{~F}$ & 5325.0 & 1.8 & $22,435.58$ & 0.73 & $6,421.33$ & & 0.286 & 1.350 \\
\hline
\end{tabular}

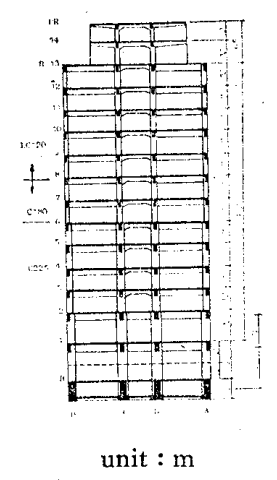

図-1（a）

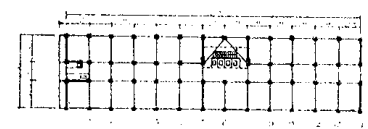

图-1(b)

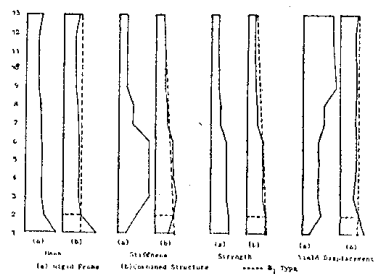

図-2

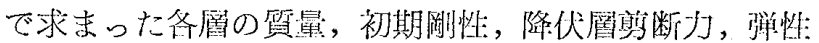

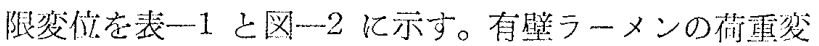
形州線についてはモデル化と関係がある。すなわち㮍断 㤠モデルとする場合隣接層以外の層の破澺の影響㹥第 2 分枝を水平にするてとによって将虑している。

5. 応答曲線による解 図一 2 亿示された請量の高さ 方向分有図を調べてみると，第1風を除䏚ば大㑣

$$
\begin{gathered}
\left\{m_{i}\right\}=\{1, \cdots 1\},\left\{k_{i}\right\}=\left\{1, \frac{121}{127}, \frac{115}{127}, \frac{109}{127}, \cdots \cdots,\right. \\
\left.\frac{61}{127}, \frac{55}{127}\right\},\left\{\beta_{i}\right\}=\left\{k_{i}\right\},\left\{\delta_{i}\right\}=\{1, \cdots, 1\}
\end{gathered}
$$

であって，てれは小班諭文による $B_{I}$ タイプの分们でる るととがわかる。したがって $B_{I}$ タイプ飞対して画が た応答刪線が利用できることになる。本建物について山

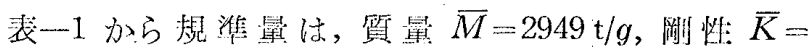
$30626.54 \mathrm{t} / \mathrm{cm}$ ，降伏尿剪断才丁 $\bar{Q}=6468,57 \mathrm{t}$ ，弹性限变: 位. $\Delta=0.212 \mathrm{~cm}$ である。また基本固有周期 $T_{1}=0.98$ 秒法猃算に上ってすで亿得られている。一方 El Centro 地震については，最大振灲 $A=0.33 g$, 継続時䦩 $T_{d}=$ 29 秒であるから, $\alpha=A \bar{M} / \bar{Q}=0.151, o=T_{d} / T_{1}=29.59$, $\therefore \alpha \rho=4.46$ となる。乙虬対して等価 5 質点系の応答 曲線少ら最大勒性率注 1 層: 2,2 層 $: 2.5,3$ 層 $: 1.2$, 4 居: 1.5，5層：0.9 となるから，本貄物はこの程度 の踢性率㚈必要之されろ。 